\title{
Am I Invisible?! Millennial Invisibility in America
}

\author{
Paris K. Wilson ${ }^{1}$ \\ College of Public Affairs, University of Baltimore, United States
}

\begin{abstract}
With social media in the 21st century, Americans can argue that the United States has become an interconnected society that exposes all people to different cultures and lifestyles. Although a powerful medium, social media has presented adverse effects that decreases the trust that Millennials, especially Black Millennials, have in American society. In this paper, Millennials ask, what is the value of the Millennial population to American society? Millennials, a creative class of individuals, are working within a system that was created without them in mind and without developing a values-based system that is comprised of empathy and an understanding of the societal challenges, Americans will continue to perpetuate a divided America amongst age groups without the proper solutions for correction. This conversation is rooted in the essence of empathy, equity, and understanding where policy and decision-making in the public and governmental organizations must incorporate to increase Millennial visibility and build a culturally competent and mentally healthier America that will benefit all. Keywords: social media, millennials, competency, invisibility.
\end{abstract}

\section{Introduction}

Millennials (anyone born between 1981 and 1996) are becoming the majority in the workforce as the Baby Boomers (anyone born between 1946 and 1964) and Generation Xers (anyone born between 1965 and 1979) are leaving the workforce, either quietly or begrudgingly through retirement. Millennials, unlike the previous generations, are motivated by their ability to create meaningful new forms of employment that dispel the Protestant conventional thoughts of America.

These views foreshadowed the American work ethic to undergo "... a spirit of thrift, hard work and efficiency that motivated the rise of early capitalism," and now this expectation has been bestowed on the Millennial generation (Florida, 2000, p. 5). In the same vein, Richard Florida (2002) explained:

Modern life is increasingly defined by contingent commitments. [Millennials'] progress from job to job with amazingly little concern or effort. In a sense where people once found themselves bound together by social institutions and formed their identities in groups, a fundamental characteristic of [their] life today... where... [they] strive to create [their] own identities. It is this creation and re-creation of the self, often in ways that reflects [their] creativity, [and] that is a key feature of the creative ethos (p. 7)

This passion for purpose and creativity obligates Millennials to lead with their hearts with the high ambitions of saving their communities within the workforce, the public sector, and the government. As Richard Florida (2002) predicted and defined, this class of people - Millennials or the Creative Class - includes:

...people in science, engineering, architecture and design, education, arts, music and entertainment, whose economic function is to create new ideas, new technology and/or new creative content. Around the core, the Creative Class also includes a broader group of creative professionals in business and finance, law, health care and [other] related fields. These people engage in complex problem solving that involves a great deal of independent judgement and requires high levels of education or human capital. In addition, all members of the Creative Class...share a common creative ethos that values creativity, individuality, difference, and merit...[and] every aspect

\footnotetext{
${ }^{1}$ Adjunct professor at the University of Baltimore, USA. E-mail: paris.wilson@ubalt.edu
} 
and every manifestation of creativity - technological, cultural and economic - [that]

is interlinked and inseparable (p. 8)

Most Millennials were raised as prodigies of the emerging workforce before the recession of 2009 and were promised if they were successful in high school, survived and graduated college, then a golden ticket would allow Millennials receive the career of their dreams. Unfortunately, this golden ticket was rejected when it was time to cash it in as Millennials emerged into adulthood after the recession of 2009.

Luckily, Millennials have had the opportunity to experience both analog and digital technology. On one hand, analog technology includes: floppy disks, VCRs, DVDs, cassette players, CDs; on the other hand, the now digital world comprises of social media, cloud technology, and wireless electronics. As a middle generation that is trapped between a compounding world of disparate technological experiences forms a social consciousness that creates a cognitive dissonance that is detrimental to the psyche of Millennials. This is explained under the theory of Émile Durkheim's "division of labor." The division of labor should become "...a categorical rule of behaviour [sic], that should be imposed as a duty (McIntosh, 1997). This division of labor creates an insular America, hence highlighting the psychological feeling of invisibility in modern society.

In contemporary American society, Millennials' feeling of invisibility offers psychological deficiencies that increases the distrust that Millennials have towards public and governmental organizations. This paper begins as an aid to professionals in public and governmental organizations to begin a culture of empathy and cultural competency towards Millennials as they commence as the future leaders in American society (Andrews, 2017). Adding to this, understanding the term and effects of "corporate psychopaths" in public and governmental organizations will prepare professionals to reengineer the cultures of their organizations that will improve their organizational practices and policies.

\section{Millennials As A Creative Class}

Millennials, similar to other generations, wish to add value to the American economy. Prior to the recession of 2009, Richard Florida's idea of the creative class describes the Millennial generation as individuals who wish to add their economic value through their creativity. Millennials add their economic value by using their creativity to solve the unfortunate and exhaustive list of social problems that Americans see today:

...education, racism, poverty, pollution, civil rights, immigration, affordable housing, individuals experiencing homelessness, terrorism, student loan debt, police brutality, moral decline, unemployment, health care reform, income inequality, bullying, corporate influence, climate change, abortion, animal rights, defense spending, childhood obesity, gun control, prison industrial complex, capital punishment, xenophobia, gender inequality, transgender issues, unfair prison sentencing, and ineffective government (Rothschild, n.d.)

Millennials acknowledge and understand that these social problems predate them and these problems require requisite solutions that will eventually become supplanted with another problem or upgraded into more severe wicked problems (Manson, 2016). Overall, Millennials want a happier America. This includes knowledge workers, analysts, professionals, generalists, and technical workers who share similar tastes, goals, desires, and preferences to socially advance America (Florida, 2002). While acquiring a diversity of skills, personalities, behaviors, and knowledge, Millennials have become highly educated individuals though formal education or informally through their life experiences.

Being highly educated contributes to the point of division of labor where Millennials are disrupting the typical trajectory of the working employee in public and governmental organizations. Although frowned upon by the older generations, Millennials bravely transition, horizontally, from job to job to obtain the skills that they want instead of obtaining the skills that have been suggested by older generations in order to become successful under antiquated American standards.

This concept of a horizontal shifts where Millennials are transitioning from position to position where they are obtaining new skills or sharpening their current skillset (Florida, 2002) and rejects the traditional vertical hierarchical career path that was foundationally laid by older generations. As a result, Millennials have become apprehensive to engage or collaborate with older generations and by abandoning the vertical hierarchical career path, Millennials are now are changing how individuals enter and navigate the workforce or democratically participate in government. This shift in thinking creates Millennial invisibility and widens the potential for intergenerational harmony amongst professionals in public and governmental organizations. 
This apprehension contorts how Millennials value their experience in the workplace. Millennials are driven to have more diversity in the workplace that includes emotion, compassion, thoughts, skills, physical appearance, and a mix of influences that appeals to their generational passion which drives the social progress that Americans are viewing today. Without a diverse community, public and governmental organizations will overtly display that outsiders are not welcomed, thus increasing the distrust with public and governmental organizations amongst Millennials.

Millennials yearn to participate in an effective and productive society and when there are apparent progressive shortcomings, they begin to battle with cognitive dissonance. Cognitive dissonance juxtaposes and attacks the status quo of an individual obtaining employment only for a paycheck, instead Millennials choose their passions that places a higher value than their paycheck. Due to the societal pushback, Millennials can feel like an outsider in the United States; consequently, this invisible feeling curates rebellious behaviors that condemns the traditional gatekeepers who manage public and government organizations.

\section{The Conscious Collective}

Many social movements are spurred from the dislike of the current environment and like many movements, individuals develop a sense of solidarity in times of disappointment of an external force. Since the world is plugged into the digital technology, it has become easy for all individuals to voluntarily merge into a collective that affirms one another through the utility of social media. In Ian McIntosh's (1997) words, “...the resistance [is] collective" and as a collective, Millennials are conscious of the errors of government and without proper access or visibility, [they] become absorbed with resisting government, increasing [their] distrust, and begin relying on themselves through entrepreneurship (p. 189). Similarly, the individual-personality consciousness contains beliefs and ideals that are attached to their character, while the collective consciousness contains beliefs and ideas that are common to the whole society.

For Millennials, the individual-personality and collective consciousness are not perpendicular and creates further frustration as their cognitive dissonance deepens. It goes without note that Millennials love and care for America and they "... wish it to prosper and endure, because without it, a great part of their psychological life would be hampered in its [antiquated] functioning" (McIntosh, p. 189). In other words, Millennials are devoted to their country and wish that the overall American population participates in this collective conscious mindset, but without the proper support, empathy, or trust from current professionals (volunteer, elected or civil positions), they will continue to resist participating in public and governmental organizations. Resulting in a psychological imbalance that affects all ages intergenerationally. However, this idea of cognitive dissonance or formally introduced as "double consciousness" is not a new idea.

Millennials are not the only generation that has felt this sense of invisibility and double consciousness. Paul Lawrence Dunbar, a freed slave who became an American poet, novelist, and playwright in the late $19^{\text {th }}$ and early $20^{\text {th }}$ centuries created a piece called, "We Wear the Masks" that eloquently described how Black people in America at that time have always lived in this country with a cognitive dissonance as both an American and as a Black American. These two states of consciousness are consistently in conflict among Black Americans and are seldom visible to the public. Dunbar (1913) stated:

We wear the mask that grins and lies,

It hides our cheeks and shades our eyes,-

This debt we pay to human guile;

With torn and bleeding hearts we smile, And mouth with myriad subtleties.

Why should the world be over-wise,

In counting all our tears and sighs?

Nay, let them only see us, while

We wear the mask.

Diving deeper, this the perfect metaphor to describe the invisibility that Black Millennials are experiencing in contemporary society. In order to survive and thrive in this society, Black Millennials have to hide their true selves, assimilate, and adapt in a system that they did not create. Black Millennials and the general Millennial population understand what has to be changed in America - either innately through life experiences or through formal schooling or a combination of the two. Black Millennials have been stripped of their voice, power, and visibility in public and governmental organizations due to the mere fact that they may have enough work experience on their resume or do 
not have enough life experiences to lead an organization because of the label of being a young or emerging professionals.

Due to Black Millennials' invisibility, their individuality is hidden throughout American society and they continuously attempt to prove themselves in a broken system and with "torn and bleeding hearts [they] smile," metaphorically speaking (Dunbar, 1913). In attempts to believe in the old adage, "picking themselves by the bootstraps," all Millennials attempt to prove themselves worthy in American society. This effort is displayed by often accepting positions with less compensation while working longer hours although the general Millennial population is on track to become the most formally educated generation to date.

Richard Fry, Ruth Igielnik and, Eileen Patten (2018) explained that Millennials “...have become more detached from major institutions such as political parties, religion, the military, and marriage. At the same time, the racial and ethnic makeup of the country has changed...[while] college attainment has spiked..." In like mind, Dunbar unknowingly speaks to the Millennial generation by saying, "why should the world be over-wise, in counting all [of their] tears and sighs?" (Dunbar, 1913). In the same vein, Millennials are planting seeds that are waiting to be sowed, but the harvest never comes. Under these circumstances, their only coping mechanism is developing a narcissistic mindset that forces them to isolate themselves in order to solve America's public problems that deepens their cognitive dissonance (Ahmad, 2016).

\section{Corporate Psychopaths: What Is It?}

The Millennial generation is becoming the majority in America. This means that Millennials are the future leaders in public and governmental organizations and without the assistance of the older generations, Millennials will begin to emerge as corporate psychopaths - a behavior that continues the demise of a broken system within public and governmental organizations that drive America.

By becoming voiceless, unheard, and invisible; Millennials will develop toxic psychopathic personality traits that fuels their feelings of inadequacy (because they were never affirmed or showed empathy by older generations), selfish values (because their double consciousness never merged into one), and deceitfulness (because they have to wear a mask to advance in the society and not show their true selves), and attempt to conceal their inner nature or individual consciousness from others (Hanson \& Baker, 2017).

Lee Hanson \& David Baker (2017) defined psychopathy as “...madness without delirium or moral insanity...[and]...was coined...to connote lack of conscience, glib charm, pathological lying, impulsiveness, and swindling in a psychopathic personality" (p. 26). To this end, the term corporate psychopath" is noted for individuals who are socially functional in adjusting to contemporary parlance or a subclinical psychopath in relation to a dysfunction which is not severe enough to present definite or readily observable symptoms. At this point, this paper shifts the term of corporate psychopaths to public and governmental organizational psychopaths to warn professionals in public and governmental organizations of this hypothesis when cultivating workplace culture and relationships with the Millennial generation.

\section{Public And Governmental Organizational Psychopaths}

There are more psychopaths gaining entry to leadership roles due to the weak entry points of public and governmental organizations: Baby Boomers and Generation Xers are leaving the workforce, rapid turnover of senior management, and the utility of shallow recruitment processes (Hanson \& Baker, 2017). These weak entry points allow for two types of subclinical psychopaths: Climbers and Zealots. Lee Hanson \& David Baker (2017) purported that "the Climber pursues self-interests over organizational interests;" on the other hand, "the Zealot exploits narrow organizational priorities to promote defiance within the organization" or rebellion (p. 30). For public and governmental organizations, these psychopaths create a double consciousness, or mask, to pursue their individualistic interests.

Entrepreneurship or private sector practices becomes attractive to public and governmental organizations because of the glamorized entrepreneurial spirit and private sector efficiency that public and governmental organizations craves. In Public Administration theory, this is called New Public Management (NPM).

New Public Management is a public administration concept where agencies are utilizing business-like methods to implement public and governmental practices with efficacy. Adding to this, Millennials are observing the NPM methods of "...rule-breaking, risk-taking, power politics, and radical change" in public and governmental organizations. These trends influence Millennials, while inadvertently, adopting these NPM methods compounded with their psychopathic traits to gain entry in spaces where they feel unwelcomed. Adopting these behaviors allows Millennials to feel welcomed, heard, and visible in public and governmental organizations. 


\section{The Dark Tetrad}

Adding to the psychopathic traits, Lee Hanson \& David Baker (2017) highlighted four "dark" personalities that professionals in public and governmental organizations should be aware of: The Machiavellian, Narcissists, Psychopath, and Sadist (p. 31). Lee Hanson \& David Baker (2017) defined each dark trait as:

[The] Narcissists are typically grandiose, demand admiration, exaggerate achievements, and resent criticism or having to compromise. The Machiavellian is cold, calculating, and morally cynical, often a social chameleon who tries to manipulate other's perceptions of mutual affinity. Psychopaths are glib, impulsive, frequently charismatic impression-managers...[and] Sadists are conspicuous for hurting others for pure enjoyment (p. 31)

Those Millennials who are high on the narcissism trait seek employment that facilitate social approval and admiration that they yearn to have in the workplace (Hanson \& Baker, 2017). The Machiavellian tries to avoid jobs that are unlikely to lead to status, notably work involving caring for others (Hanson \& Baker, 2017). Psychopaths are labeled the meanest of the Dark Triad and have a sense of entitlement and lack of empathy which causes antisocial behavior, where Sadistic patterns amounts to aggressive or malignant behaviors (Hanson \& Baker, 2017). Psychopaths, narcissists, and Machiavellians all have been found to admit prejudice against people of color and for the purpose of this manuscript, this paper will now focus on the narcissist dark trait as it pertains to Millennial invisibility in society (Hanson \& Baker, 2017).

\section{The Millennial Narcissist}

In contemporary society, "likes" on social media and the hunger for validation are the social currency and a chief function of Millennial narcissism. Jeffrey Kluger (2014) emphasized on a subclinical level - that Millennial:

...narcissism is a much more common phenomenon. And the business world with its premium on aggression, achievement, and recognition, self-selects for this trait in a way that more other-directed fields in [the public sector] like nursing or social work don't. People who enter the [public] service field are inclined to want to give; those who enter the corporate world are at least a little likelier to want to take [empathy into consideration] (p. 86)

Focusing on professionals in public and governmental organizations, “...there are few fields that...perfectly meld and reward the combination of greed, ambition, lack of empathy and overwhelming ego that defines this condition" of Millennial narcissism (Kluger, p. 129). As a result, Millennials have weaponized their narcissism through social media to isolate themselves and appear visible, digitally, in the general American society where they feel invisible. To rectify this, Millennials crave to become "verified" - a blue check next to their name - on social media platforms. For Millennials, becoming verified awards the highest return on investment of participating in the social media arena because this garners a status symbol that gives them the attention, trust, influence, and respect they yearn for.

This is a modern concept to grapple for previous generations because adapting this narcissistic behavior generally works in the favor of the Millennial and their success "...is tilted in their direction - rewarding energy, cockiness and barely contained arrogance, and ignoring or even penalizing quieter..." personalities (Kluger, p. 137). As the Millennial generation aged from their youth to their adulthood, they were pushed by Baby Boomers and Generation Xers to achieve at the highest levels, enhance their confidence, and become successful according to antiquated American standards, even when their mental and emotional capacity is sacrificed.

Developing a bombastic personality gives the perception that Millennials are "...brave [because] they radiate charismatic energy [as] they self-promote" themselves and [become] irresistible with their "...wit and energy whether you're in a bar, at a party or sitting across a boardroom table, and a person in possession of those qualities is someone.." that older generations want to collaborate with (Kluger, p. 137, 138). Comparatively, with the excitement of "going viral" (a meme, gif, or video that rapidly spreads through social media) is highly valued for Millennials. Going viral buttresses the adoption of narcissistic behaviors of Millennials to feel visible, respected, and heard. 
On one hand, when Millennials display their achievements, they receive the admiration of their "followers" with reposts and retweets on social media which engenders an insatiable thirst to feel socially, emotionally, and intellectually validated and visible - a position that Millennials are looking for when dealing with the general American society and the previous generations. On the other hand, when Millennials are criticized and not heard, they begin to feel invisible, a reality that Millennials feel today. With an increase of Millennial invisibility, social isolation, and societal distrust increases their narcissism that imbalances their psyche as they attempt to survive and thrive in America.

\section{Black Millennials, Social isolation, And Political Distrust}

Narrowing the focus to Black Millennials, Millennial invisibility creates a vicious cycle of social isolation and societal distrust. According to conventional wisdom, it is assumed that as the nation's conditions improve, then trust in public and governmental organizations and society increases (Mangum, 2016).

If Americans analyze the conditions of the overall Black populations compared to White populations through the vastness of information and social media, the Black community remains in the worst economic positions than Whites communities. Black communities across America can compare and contrast living conditions that further fracture their relationships within American society, thus deepens their social isolation and invisibility as they notice that social progress within the Black community continues to move slowly (James, 2018; Mangum, 2016). If the Black community observes the Whites community doing better economically and socially, then they will not trust the general American society nor public and governmental organizations because of their assumed complicity. Interestingly enough, becoming formally educated contributes to Black Millennial invisibility and societal distrust. Maruice Louis Mangum (2016) plainly stated that formally educated:

African Americans should be more likely to know the political system and to know how the government continues to treat African Americans differently, often worse than whites. A formal education allows them to know [the] better [part of] history of [the] harsh treatment of African Americans in the United States. They pay more attention to public affairs...[and]... are more sensitive to how policies affect people differently...[and]...know how and why African Americans remain disadvantaged economically, socially, and politically compared to white Americans...times have changed [politically], but the lack of resources remains the same...[and]...they become more aware of the gap between their resources and those of other groups (p. 87)

Becoming formally educated leads to political and societal distrust, because Black Millennials have studied American history, coupled with the contemporary theories and their lived experiences. These individuals endure institutional and structural racism, discriminatory policies, and pejorative practices in their communities that is the foundation of American society. Institutional and structural racism are defined as a complex of embedded, systemic practices that disadvantages racial and ethnic groups through public policies and governmental programs (Seabrook \& Wyatt-Nichol, 2016).

To curb this, professionals in public and governmental organizations must employ empathy to Black Millennials and empower them to become heard and visible in American society. This solution should start as early as grade school and through intentional interventions and services in their communities; as a result, the Black community and Black Millennials will not experience the contemporary lynchings of covert and overt racism, institutional and structural oppression, and discriminatory policies in America.

\section{Living As A Black Millennial}

Living as a Black Millennial in America is an arduous task. Many Black intellectuals like Paul Lawrence Dunbar, Carter G Woodson, and W.E.B. Du Bois have scaffolded these theories of living a dual life (or double consciousness as explained previously) that are still relevant to Black Millennials in the $21^{\text {st }}$ century. As aforementioned, this paper discussed Dunbar's theory of Black Americans, wearing a mask, and opens the door to Carter G. Woodson's theory of the American Negro living this dual life and utilizing this concept better describes the Black Millennial experience in America.

Woodson (1933) informed his readers that Black Americans must be social and bisocial [sic] at the same time (p. 6). In this case, Black Millennials must maintain his/her social capital in the Black community, while increasing and maintaining their social capital with the general American society - a double consciousness that depletes Black individuals socially, emotionally, physically, and mentally. 
While being a good American, [Millennials] must above all things be a "good Negro;" and to perform this function [they] must learn to stay in a "Negro's place" (Woodson, 1933). This sense of place in this context was in the field, in the maid's quarters, or in the back of the bus (Seabrook \& Wyatt-Nichol, 2016) and if a Black person was "out of [their] place," they could be punished, jailed, or lynched.

Unfortunately, in contemporary society, Americans see the consequence of a Black Millennial being out his place through the former quarterback, Colin Kaepernick. A peaceful demonstrator who kneeled during the American national anthem in response to the police brutality of Black Americans on an American public stage, a National Football League field. The actions towards Colin Kaepernick is similar to the Willie Lynch letters, a fear tactic used as a strategy to socially, mentally, and physically control slaves. Notwithstanding, the indirect and direct teachings of place, the consequence of being out of place impacts the Black community in American society where a feeling of belongingness and visibility is a foreign concept.

Today, Americans do not publicly refer to Black Americans as "Negros," however this statement still holds significant weight. Because of contemporary society, developing agency, advocacy, and visibility is praised but myopic. Using the example of Black Lives Matter, at its onset, is an advocacy organization that is geared towards fair treatment with the police and at its simplest form, is a thought that should be considered across all communities. In reality there were rallies nationally and internationally, which raised tactless concerns from individuals with opposing views to undermine their message as hate speech and violent; consequently, villainizing peaceful protesters without a clear understanding of the purpose of this movement that was organized by Black Millennials.

Unbeknownst to the overall American society, social unrests and racial turmoil has existed in America since the American revolution of 1765 (Seabrook \& Wyatt-Nichol, 2016). Throughout history, institutional oppression and structural racism has been the overarching form of social control used to maintain dominance over the Black community and these historical events has altered the social fabric of race relations between the Black community and the majority White American population (Seabrook \& Wyatt-Nichol, 2016).

All in all, Black communities are hopeful, especially at the turn of the Barack Obama era of "hope" politics - wishful political and social actions that will curb the social ills of the past - as they continue to keep up the good fight towards social, racial, and political equity. The Black performance of being heard, loud, and visible is kept up for a while; but, like any other effort at meaningless imitation to do things the right way, it continuously results in failure (Woodson, 1933). As American born citizens who are granted with the First Amendment, it is the constitutional right of Black Millennials to voice their opinions of the transgressions that are occurring towards their community, but undermining their experiences through fear tactics and villainization devalues all schools of thought, opinions, and historical facts, thus proving the point that these individuals are continuously marginalized in America.

Again, not being able to cash in their golden ticket of surviving and graduating high school, Black Millennials enter their institutions of higher learning (IHLs) to prepare themselves for the uplifting of their communities (Woodson, 1933). When Black Millennials first arrive to their respected IHLs they often labeled (intentionally or unintentionally) with the following marginalizing markers: first-generation college student, PELL grant and/or work study recipient, or at-risk student. Unfortunately, these markers have been used to socially and academically controlled Black Millennials before arriving to their college campus. The traditional school of thought was to train youth for jobs for a dissolved industrial economy by demanding the memorization of historical and contemporary facts to pass examinations for jobs with capped skills to become another dispassionate employee in the American economic system instead of a trailblazer or leader (Woodson, 1933). Facing this undesirable result, the highly educated Black Millennial often grows sour and begins to isolate themselves as a coping mechanism (Woodson, 1933). As a result, pessimism is weaponized and becomes a constructive force that develops into chronic complainants at the bar of public opinion (Woodson, 1933).

In like mind, W.E.B. Du Bois" theory of "double consciousness" aligns with Dunbar and Woodson that Black Millennials live in a dual world attempting to maintain their visibility in America. He states that:

...this double consciousness, this sense of always looking at one's self through the eyes of others, of measuring one's soul by the tap of a world that looks on in amused contempt and pity. One ever feels his twoness, an American, a Negro; two souls, two thoughts, two unreconciled strivings; warring ideals in one dark body, whose dogged strength alone keeps it from being torn asunder...[Black Millennials] simply wishes to make it possible to be both a Negro and an American, without being cursed and spit upon by his fellows, without having the doors of Opportunity closed roughly in [their] face (Du Bois, 1903, p. 6) 
This "twoness" that Du Bois refers to affirms that Black Millennials live in this dual world attempting to find their way in the general society of America. Insomuch that Black Millennials begin to rally others as a collective to protect their personal considerations and communities. Ta-Nehisi Coates speaks to the violence, political distrust, and citizen engagement amongst Black people and implies that Black Millennials have contorted their bodies in two ways: losing their individualism to address their block (neighborhoods and communities where they reside) and contorted again losing their individualism to be taken seriously by their older colleagues (Coates, 2016).

\section{Black Millennial Hardness}

The community adage of Black Millennials who are raised in society is to become "twice as good" as their counterparts to thrive in this world, but when they have shortcomings or exhausted from living a dual life, they tend to assimilate to whiteness and resentfully accept this feeling of invisibility. Ta-Nehisi Coates would label Black Millennials as "...losing their softness..." while being stolen of their smile of living in a utopia where they are heard, visible, and accepted as who they are instead of who they are not; consequently, they adapt a hardness that is impenetrable by family, friends, and their workplaces (Coates, 2016).

Black Millennials are all too familiar with the historical role that race has played in the construction of society, culture, and politics (Kang, 2016). This hardness is warranted due to the long history of despair, sadness, and disappointment which draws them away from society and their ability to trust public and governmental organizations or the general American society. Black communities continue to become the victims of being excluded from power, exploited, and discriminated against which leads them to perceive society through a racial group lens (Mangum, 2016).

Trust with public and governmental wades in the water for Black Millennials. Their trust ebbs and flows as they attempt to live a dual life while dealing with their cognitive dissonance where they want to trust complicit organizations. Nevertheless, Black Millennials' strive for high educational attainment because they want access to the American dream; however, due to traumatic communal and familial history, Black Millennials often fall short.

\section{Black Community Trauma}

Magnum (2016) describes trauma by explicitly stating that African Americans' learn from family and friends through stories or their own life experiences that highlights the harsh realities of being a Black person in America. As youth, Black Millennials are informed of the following: slavery, lynching, the Ku Klux Klan, the school to prison pipeline; as well as economic indicators such as, income, the unequal wage gaps, educational attainment rates, and White-on-Black crimes. These factors reveal the progress of racial inequities that are compounded with the forms of mistreatment and racially socialized experiences before Black youth are awarded the knowledge of the contribution that Black Americans have provided for the United States of America (Kang, 2016; Magnum, 2016). Adding to this, as adults, these negative and traumatic experiences are heightened with the state of social media with the constant circulation of damaging images and videos of mistreatment of Black people within America.

In other words, Seong Kang called this group implication, which is the process where issues engage a Black Millennial's ideas about their social categories that shapes their public opinion (Kang, 2016). This group implication is a form of reasoning by analogic experiences where people seek to comprehend unfamiliar subjects of or events by way of referring to familiar domains of experiences or linked fate (Kang, 2016). Shifting from this concept to chosen trauma, both theories are centered around storytelling and these narratives increase Millennial distrust in public and governmental organizations in America. Vamik Volkan (2001) defined chosen trauma a concept that:

...hypothesizes [the] mental representations of an event in a group's history in which it has suffered a catastrophic loss or humiliation at the hands of others may, in the absence or proper mourning, be handed on to subsequent generations in the form of injured images and projections of oppression. These representations of the trauma may link together all of the individuals in a large group. When passed on, a next generation may feel compelled consciously or unconsciously to right the wrongs done to their ancestors and the concept of trauma as a mental representation also becomes a marker of group identity

These forces of chosen trauma and the instinctive forces of affinity of blood lines (family), attachment of the same soil (community), the cult of their ancestors (generational familial knowledge), and a commonality of habits (utilizing social media to feel visible) contributes to the displacement and invisibility of Black Millennials in America (McIntosh, 1997, p. 196). These natural inequities are described as testing intelligence quotient (IQ) levels and assessing that the higher the IQ score, the more intelligent a student is which then equates to a higher educational attainment they will earn and a higher quality of life. More narrowly, if intelligent Black children have proven their 
academic aptitude, but are enrolled in failing schools, these students are doomed to fail due to the fractured school systems, institutional oppression, and discriminatory policies and pejorative practices. Unfortunately, Black children are socialized from early age to recognize race, gender, and class differences and instructed to act in their respective place for their safety.

These distinctions are important for adults in the comprehension of social and political constraint (Kang, 2016). This constraint is a struggle for Black Millennials because they do not want to become displaced, out of their place, or not allowed to fight for equitable policies and practices. Thus, adding to their invisibility because of the lack of access to resources and suffering they endure socially, politically, and culturally, while living with this dual life that they inherited since their birth.

A misunderstanding of Black community trauma and Black Millennials transfers to a lack of competency that should be measured and weighed in public and governmental organizations. These issues are twofold. First, there is a misunderstanding of the Black community. Second, there is a misunderstanding of the values of the Black Millennial generation. These issues remain alive in American culture because the understanding of the Black community and Black Millennials seems like an individual problem instead of a societal problem; hence, further engendering a disconnect between Black Millennials and the general Millennial population.

\section{Millennial Generational Disconnect}

Overall, there is a known disconnect between the general Millennial population and previous generations. Acknowledging the disconnection, Millennials like Ermias Asghedom (rapper Nipsey Hussle) are "...more focused on giving solutions and inspiration more than anything" and Millennials expect effective interventions from yesterday because of the alarming effects that contemporary society faces today (Kondo, 2010).

Millennials wish for American citizens to become culturally competent in public and governmental organizations. Thomas Longoria and Nandhini Rangarajan (2015) emphasized that “...cultural competence refers to one's ability to appropriately harness cultural knowledge, awareness, skills, attitudes, behaviors, values, and experiences crafting effective responses to address culturally unique needs" (p. 2).

This amalgamation of abilities displays that this work of cultural competency, notably with Millennials, is an arduous task and "at 80 million strong, [Millennials] are the biggest age grouping in American history...[and] because of globalization, social media.... and the speed of change, millennials... are more similar to one another than to older generations within their nations" (Stein, 2012). Although connected through social media, there are stark differences between the overall Millennial generation and Black Millennials in terms of equity. Without equity, this deepens the chasm between Millennials and Black Millennials due to the level of social, professional, and political access that are not afforded to Black Millennials because of the construction of social and racial groups coupled with structural and institutional racism.

These factors allow Millennials to notice the disconnect between their generation and previous generations. Knowing this information, these fractured relationships stem from a lack of empathy and insufficient relationship building when older generations and Millennials are in direct contact with one another. Adding to this and placing individual perspectives aside, culturally incompetent professionals must realize that this does not excuse their programs, policies, and practices from being culturally incompetent.

\section{Public and Governmental Practices}

Americans can attest that every citizen wants a high quality of life with policies that represents their community fully. As stated previously, America is a diverse and interconnected nation more than ever because of social media; insomuch, that America has a "diverse" physical representation in all levels of government, but the challenging point is these spaces does not equate to equitable representation. Once public and governmental organizational spaces begin the legwork of increasing their diversity through equitable practices and all identities are accepted, then the American people will begin to see policies and practices that reflect their community. For this reason, it is important to explain the differences between equal (passive) and equitable (active) practices.

\section{Passive Public And Governmental Practices}

Passive representation as Vicky Wilkins \& Brian Williams (2008) suggested “...is concerned with whether the bureaucracy has the same demographic origins - sex, race, income, class, religion - as the population it serves" (p. 655). In other words, professionals who passively represent their organization has the perception of "not seeing color" and America is a colorblind society. This is problematic for Millennials. As a globally interconnected generation who 
embraces many lifestyles and identities, this mindset discredits the Millennial individual who enjoys being different and accepted for their differences.

Having public and governmental organizations that passively represents society adds to the Millennial mindset that professionals in these organizations are accustomed to having disconnected, fractured, and transactional relationships. Meaning, these transactional relationships are only seemed as beneficial if the other party receives a benefit as well, if not, it will become a zero-sum relationship. Millennials are changing this mindset with empathy in mind to charge every relationship as positive-sum relationships where both parties benefit from an interaction. With passive representation in public and governmental practices, on a surface level, these organizations may seem diverse in theory, but in the praxis and execution, these policies and practices are not given the thought of how their policies may influence a wider racial, cultural, and social gap.

\section{Active Governmental Practices}

On the other hand, active representation grants professionals in public and governmental organizations the ability to transfer how diversity is treated and fostered in America. Adding depth to professionals with equitable public and governmental practices in mind, Vicky Wilkins \& Brian Williams (2008) stated that active representation is concerned "... with how [active] representation influences policy making and implementation" (p. 656). Adding to this definition, active representation gives professionals the authority to balkanize programming to provide equitable policies and practices to all Americans (Carothers, 2018). This concept is the turnkey to correct repugnant passive representation practices in public and governmental organizations; with this, professionals must become intentional and genuine with their practices to cater to a diverse America in order to add value to the public good by serving American citizens (Cicek, Ulker \& Tarman, 2012).

\section{Garbage Can Practices}

Now, acknowledging passive representation as a foundation to cater to diversity with the hopes that active representation should become the American standard. Conversely, most professionals might argue and challenge that there is not enough time to strategize and create the "right" policies that serves all communities equitably. This leads us to what Michael X. Cohen, James G. March, and Johan Pelck called the "Garbage Can Model of Organizational Choice."

Most public and governmental organizations have "...a collection of choices [that look at] problems, issues, and feelings...for decision situations in which they might be aired, [and the] solutions look for issues to which they might [have] the answer" (Cohen, March, \& Olen, 1972, p. 2). Compounding and comprehending two general properties theory, this guides public and governmental decisions. The first general property is, problematic preferences. Michael X. Cohen, James G. March, and Johan Pelck (1972) addressed this property as the difficulty:

...to impute a set of preferences to the decision situation that satisfies the standard consistency requirements...the organization operates on the basis of a variety of inconsistent and ill-defined preferences. It can be described better as a loose collection of ideas than as a coherent structure; it discovers preferences through action more than it acts on the basis of preferences (p. 1)

Millennials are taking note of these inconsistencies in society, especially when there are apparent disparities between white and Black citizens in America.

The second property to acknowledge is fluid participation. Michael X. Cohen, James G. March, and Johan Pelck (1972) identified fluid participation as "participants [that] vary in the amount of time and effort they devote to different domains.... as a result, the boundaries of the organization are uncertain and changing; the audiences and [the] decision makers for any particular kind of choice change capriciously" (p. 1). Knowing these properties brings light to the idea of a garbage can theory in public and governmental organizations.

Uniquely stated, the properties within the garbage can theory are "...various kinds of problems and solutions [that] are dumped by [professionals] as they are generated" then the solutions become "...decisions as an outcome or interpretation of several relatively independent streams within an organization" without much strategy or thought (p. $2,3)$. For the citizens and professionals, this theory is common and noticeable because public and governmental organizations can create the policies and retroactively corrects social problems. For example, Barack Obama creating the Affordable Care Act to give all citizens access to affordable health care - although it is not the most successfully implemented federal policy, the policy was in place to ensure that all Americans had some form of access to affordable health care. 
Although corrective actions are in place, Millennials observe various garbage can policies that adds to their feelings of disappointment, disgust, and anger. Having unclear boundaries or goal ambiguity in public and governmental organizations creates a mission mystique within organizations (Kopish, 2016). A concept that Charles Goodsell (2011) described professionals who are "...not merely [passionate] to implement laws faithfully or to run programs efficiently..." as a result, creates organized anarchies that "...are particularly conspicuous in public, education, and various organizations" (Goodsell, p.2; Cohen, March, and Olsen, p. 1). Again, all American citizens want professionals in public and governmental organizations to actively represent them and publicly display they are serving American citizens to add value to their quality of life and the public good.

\section{Servant Leadership}

Within the arena of public and governmental organizations, there have been various theories and models in the public administration field that can change the American society. Starting with Old Public Management, this model portrayed conventional public administrative values that were homogenous and self-serving to the declining white majority of the population. The upgraded model for public administration was called, New Public Management. Janet Denhardt \& Robert Denhardt (2000) described this as a model as:

...the political (or policy) process, the choice of efficiency (as opposed to responsiveness, etc.) as the primary criterion for assessing the work of administrative agencies, and an emphasis on designing public agencies as largely closed systems, featuring a single controlling executive having substantial authority and operating in a top-down fashion (p. 25)

At this point, if Americans know anything about Millennials, the now majority generation of 80 million globally, this approach to top-down management is not conducive to their ideals and beliefs. Next, moving from Old Public Administration to New Public Administration, Janet Denhardt \& Robert Denhardt (2000) addressed a concept called New Public Service which holds:

...government [accountable to] engage in only those activities that cannot be privatized or contracted out and that, more generally, market mechanisms [that are] employed wherever possible so that citizens will be presented with choice among service delivery options... [as] a special role for managers, especially entrepreneurial managers, who are given greater latitude in improving efficiency and productivity, primarily though managing for results. Finally...public managers [should] steer rather row, that is, they move toward becoming monitors of policy implementation or purchases or service rather than being directly involved in [the] service delivery itself (p. 26)

In other words, the concept of steering, not rowing, explains that professionals should utilize a positive mindset, opposed to a deficient mindset to the general Millennial population. This deficient mindset stems from professionals who, intentionally or unintentionally, label themselves as saviors rather than a server of the American public.

For Millennials who are taxonomized as the creative class, allowing them to become a collaborator of how America should implement policies and best practices are essential for forward progress (Bittman, \& Russell, 2016; Domingo \& Guerrero, 2018; Strunc, 2019). Adding to the term "entrepreneurial manager," professionals must encourage collaboration with Millennials to ensure equitable policies and programs that actively represents all people at the onset policy and practice implementation.

For the general Millennial population, cultivating relationships where they are presented as a stakeholder in the decision-making process allows professionals to adopt the mindset of servant leadership that is essential for effective change in American society. Without this inducement of servant leadership in professionals in public and governmental organizations, Millennials will continue to grow sour, isolate themselves, and remain invisible who, then, will react as vigilantes to solve their community's problems without the assistance of individuals within the previous generations. 
Wilson, P. K.

\section{Recommendations For Change}

Previous generations may ask, what does collaboration, servant leadership, and empathy towards Millennials look like in an everchanging America? There are three strategies that are described in the following paragraphs.

The first strategy is strategizing how to become more collaborative and empathetic towards Millennials with an equity and servant leadership lens. This empowers Millennials to become visible in public and governmental organizations by including them in the decision-making process regardless of age, educational attainment, and professional experience.

For Black Millennials, the second strategy is understanding the historical context and race relations of the Black community. Understanding the history of race in America and the institutional oppression that thrives in Black communities should employ professionals to display empathy and recognize the traumas and adverse life experiences that these communities are grappling with in America. Employing an empathetic understanding of the Black community gives comfortability to Black Millennials to share their opinions and have their voice heard even when there are opposing views present. The goal here is to reduce the minimalization of the Black Millennial voice and create a space to strategize so they can add value to public and governmental organizations.

The third strategy is providing spaces where the general Millennial population can thrive. This means opening the door to access and opportunities, while exhibiting respect and trust for them to have a seat at the decision-making table and believing that Millennials have verified information and authentic lived experiences that has shaped their perspectives. Following these three steps will ensure that the all Millennials feel welcomed, respected, trusted, and most importantly visible in a society that continues to oppress and ignore the valuable experiences that these individuals have living in America.

\section{Conclusion: Why Should Americans Care About Millennial Invisibility?}

Millennial invisibility is problematic for the future America. As a generation that Richard Fry, Ruth Igielnik, and Eileen Patten (2018) acknowledged as "more than one-in-three [of the] American labor force participants (35\%) and in 2017, “...9 million post-Millennials (those who have reached working age, 16 to 20) were employed or looking for work..." Knowing that Baby Boomers and Generation Xers are retiring, the numbers of these individuals within public and governmental organizations are declining. Coupled with this, Richard Fry, Ruth Igielnik, and Eileen Patten (2018) explained:

...the Millennial labor force is still growing [and] The Census Bureau projects that the Millennial population will peak at 75 million...[and] as of 2017 - the most recent year for which data are available - 56 million Millennials (those ages 21 to 36 in 2017) were working or looking for work. That was more than the 53 million Generation Xers, who accounted for a third of the labor force. And it was well ahead of the 41 million Baby Boomers, who represented a quarter of the total. Millennials surpassed Gen Xers in 2016 (Fry, Igielnik, and Patten, 2018)

Why is this important? There are 56 million Millennials who are looking for work that incorporates entrepreneurship, learning, and the latitude to create to solve public problems. In order for America to succeed, systems must be fixed or Americans will continue to operate in fragmented society. At this point, Millennials have enough life experiences to see the errors of the older generations and the maltreatment of the public and governmental organizations and, rightfully so, Millennials jaded (and possibly cringe) when previous generations discuss the American dream.

When professionals comprehend and respect the notion that Millennials want loyalty, inclusion, and transparency in public and governmental organizations, then Millennials will decide to increase their participation and trust in America. If not, there will be a continuum of narcissistic individuals who will develop stark individualistic behaviors within public and governmental organizations; in turn, these narcissistic individuals will have the potential and opportunity to create policies and programs that will inhibit social good and further decrease morality, loyalty, and invisibility in America. As stated previously, to curb Millennial invisibility, especially Black Millennial invisibility, professionals in public and governmental organizations must lead their organizations with servant leadership and empathy in mind to evoke a more progressive, collaborative, and productive America for Millennials and future generations. 


\section{Biographical Note}

Paris K. Wilson is a Masters Public Administration student, Writing Center Fellow, and an adjunct professor at the University of Baltimore, where he teaches entry-level writing and rhetoric courses. His research includes public administration, intergenerational relationships within public administration, public health and mental health trauma, and writing center pedagogies that discusses Black language and dialect.

\section{References}

Ahmad, I. (2016). The Early Years of American Political Science: Traditionalist Paradigm and its Critics. Research in Social Sciences and Technology, 1(2). Retrieved from https://ressat.org/index.php/ressat/article/view/17

Andrews, K. (2017). Culture, Curriculum, and Identity in Education. [Book Review]. Journal of Ethnic and Cultural Studies, 4(2), 99-101.

Bittman, B. L., \& Russell, W. B. (2016). Civic education in united states: A multiple regression of civic education scores from the national assessment of educational progress. Research in Social Sciences and Technology, 1(2), 1-23.

Carothers, D. (2018). A culture of equality?. Journal of Culture and Values in Education, 1(2), 42-57. Retrieved from http://cultureandvalues.org/index.php/JCV/article/view/13

Cicek, V., Ulker, R., \& Tarman, B. (2012). Comparison of character education in US and Turkish educational systems: Globalizing American education system. Energy Education Science and Technology Part B: Social and Educational Studies, 4(3), 1311-1322.

Coates, T. (2015). Between the world and me. New York, NY: Penguin Random House.

Cohen, M. D., March, J. G., \& Olsen, J. P. (1972). A garbage can model of organizational choice. Administrative Science Quarterly, 17(1), 1-25.

Denhardt, R. B. \& Denhardt, J. V. (2000). The new public service: Serving rather than steering. Public Administration Review, 60(6), 549-559.

Domingo, S., \& Guerrero, N. (2018). Extent of Students' Practices as Digital Citizens in the 21st century. Research in Social Sciences and Technology, 3(1), 134-148. Retrieved from https://ressat.org/index.php/ressat/article/view/353

Du Bois, W. E. B. (1903). The souls of black folk: An American heritage books. Radford, VA: Wilder Publications LLC.

Dunbar, P. (1913). "We Wear the Mask". Lyrics of Lowly Life (Lit2Go Edition). Retrieved from https://etc.usf.edu/lit2go/187/lyrics-of-lowly-life/3819/we-wear-the-mask/

Florida, R. (2002). The rise of the creative class: And how its transforming work, leisure, community, \& everyday life. New York, NY: Basic Books.

Fry, R., Igielnik, R., \& Patten, E. (2018, March 16). How millennials today compare with their grandparents 50 years ago. Pew Research Center. Retrieved from https://www.pewresearch.org/fact-tank/2018/04/11/millennialslargest-generation-us-labor-force/

Goodsell, C. T. (2011). Mission mystique: Belief systems in public agencies. Washington, DC: CQ Press.

James, W. Y. (2019). Imprint of Racism: White Adult Males' Transformational Experience from Racial Antipathy to Racial Reconciliation. American Journal of Qualitative Research, 3(1), 93-116. https://doi.org/10.29333/ajqr/5813

Hanson, L., \& Baker, D. L. (2017). Corporate psychopaths in public agencies? Journal of Public Management, 21-41.

Kang, S. C. (2016). Race relations in America: Complacency all along? Journal of Public Management Social Policy, 23(1), 73-77.

Kluger, J. (2014). The narcissist next door. New York, NY: Riverhead Books.

Kondo, T. (2010). Interview: Nipsey Hussle talks african roots, snoop dogg co-sign, and rappers reppin' gangs. Complex Magazine. Retrieved from https://www.complex.com/music/ 2010/04/interview-nipsey-hussletalks-african-roots-snoop- dogg-co-sign-and-rappers-reppin-gangs

Kopish, M. A. (2016). Preparing globally competent teacher candidates through cross-cultural experiential learning. Journal of Social Studies Education Research, 7(2), 75-108.

Longoria, T., \& Rangarajan, N. (2015). Measuring public manager cultural competence: The influence of public service values. Journal of Public Management \& Social Policy, 21(1), 1-18.

Mangum, M. (2016). Explaining political trust among African Americans. Journal of Public Management \& Social Policy, 23(2), $84-100$.

Manson, M. (2016). The subtle art of not giving a fuck. New York, NY: HarperCollins Press.

Mcintosh, I. (1997). Classical sociological theory: A reader. New York, NY: New York University Press. 
Rothschild, M. (n.d). The social issues you care about most. Ranker. Retrieved from https://www.ranker.com/list/social-issues-in-america-that-you-care-about-most/mike-rothschild

Seabrook, R., \& Wyatt-Nichol, H. (2016). The ugly side of America: Institutional oppression and race. Journal of Public Management \& Social Policy, 23(1), $20-46$.

Stein, J. (2013, May 20). Millennials: The me me me Generation. Time Magazine: U.S. Retrieved from http://time.com/247/millennials-the-me-me-me-generation/

Strunc, A. (2019). The Politics of Culture. Journal of Culture and Values in Education, 2(1), 71-80. Retrieved from http://cultureandvalues.org/index.php/JCV/article/view/26

Volkan, V. (2001). Transgenerational transmissions and chosen traumas: An aspect of large-group identity. Group Analysis, 34(1), 79-97.

Wilkins, V. M., \& Williams, B. N. (2008). Black or blue: Racial profiling and representative bureaucracy. Public Administration Review, 654 - 661 .

Woodson, C. G. (1933). The mis-education of the negro. Trenton, NJ: Africa World Press. 